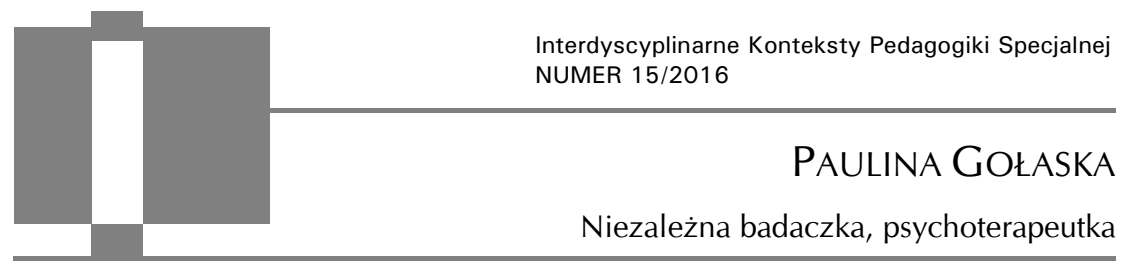

\title{
Autyzm relacyjnie, czyli praca na i nad kontaktem z dziećmi z zaburzeniami ze spektrum autyzmu ${ }^{1}$
}

\begin{abstract}
Paulina Gołaska, Autyzm relacyjnie, czyli praca na i nad kontaktem z dziećmi $z$ zaburzeniami ze spektrum autyzmu [Relational approach to autism. Connection as a strategy and a goal of therapeutic work with children with autism spectrum disorders]. Interdyscyplinarne Konteksty Pedagogiki Specjalnej, nr 15, Poznań 2016. Pp. 65-78. Adam Mickiewicz University Press. ISSN 2300-391X
\end{abstract}

Relational approach to autism is a specific way of understanding needs of the child with development disorders based on three strong fundaments - psychoanalysis, development psychology and psychopathology. It is a result of complex research of typical development and identification of caretaker's intuitive reactions, which support the child best and in a natural way. Relational therapy is not a remedy for every issue in autism. However, it should be an important, central element of a good-enough, holistic educational and therapeutic program. An introduction to other, educational-oriented activities, like learning which is a dyadic process of interaction between two people of whom one is always a teacher for another. Connection and relation should be an essence of every intervention dedicated to autistic children to, as a result, make the autism thaw ${ }^{2}$.

${ }^{1}$ Niniejszy artykuł jest efektem realizacji projektu badawczego „Klasyczne i nieklasyczne psychoanalityczne ujęcia zaburzeń ze spektrum autyzmu” finansowanego ze środków przyznanych przez Polskie Towarzystwo Psychoterapii Psychoanalitycznej. Szczegółowy opis projektu dostępny jest na stronie internetowej: www.autyzm relacyjnie.pl

2 A. Alvarez, The thinking heart: three levels of psychoanalytic psychotherapy with disturbed children, Routledge, London 2012. 
KEY WORDS: autism spectrum disorders, relational therapy, psychoanalysis, connection, agreement

Trudności w porozumiewaniu się z otoczeniem zaliczane są do głównych symptomów zaburzeń ze spektrum autyzmu. Niemożność lub niechęć nawiązania kontaktu z innymi osobami uniemożliwia uczenie się, a przez to blokuje całościowy i wszechstronny rozwój dziecka. Działania terapeutyczne skoncentrowane na wspieraniu dziecka $\mathrm{z}$ autyzmem w budowaniu i utrzymywaniu znaczących, wartościowych relacji powinny stać się osią wszelkich oddziaływań i podstawą wprowadzania dalszych, zorientowanych edukacyjnie interwencji. Posłuszniejsze czy lepiej wyedukowane dziecko z pewnością będzie źródłem satysfakcji dla związanych z nim dorosłych - rodziców, nauczycieli, terapeutów - lecz dziecko bardziej zainteresowane światem, wchodzące z przyjemnością w znaczące dla siebie relacje $z$ innymi będzie nie tylko źródłem radości dla innych, ale i szczęśliwym człowiekiem dla samego siebie³

\section{Wiedza i umiejętności terapeuty pracującego z osobami z autyzmem}

Interwencje skoncentrowane na pracy na i nad relacją nie muszą, a wręcz nie powinny konkurować z oddziaływaniami behawioralnymi, stricte edukacyjnymi. Te dwa podejścia bowiem jedynie w teorii się wykluczają, a toczące się między przedstawicielami obu nurtów spory zdecydowanie nie pomagają, lecz przeszkadzają w planowaniu i wdrażaniu skutecznych, holistycznych programów terapeutyczno-edukacyjnych. Niemniej obecnie w procesie kształcenia akademickiego studentów, a także w dalszym szkoleniu praktyków, bardzo duży nacisk kładzie się na kształtowanie umiejętności „twardych” - wyposażanie w odpowiednią wiedzę metodyczną,

\footnotetext{
${ }^{3}$ Ibidem.
} 
zapoznawanie z określonymi, wysoce wyspecjalizowanymi metodami pracy, przygotowywanie precyzyjnych, dokładnie zaplanowanych, szczegółowo opisanych planów oddziaływań, które są w istocie swej dość wąsko rozumianą edukacją, często pozbawioną wręcz pierwiastka humanistycznego i ludzkiego wymiaru. Osią wszelkich oddziaływań w terapii dzieci autystycznych powinna być relacja. Od jej zbudowania - w przypadku młodszych dzieci relacji z rodzicami, w przypadku starszych zaś relacji z terapeutą - powinno rozpoczynać się każdorazowo inicjowany proces diagnostyczno-terapeutyczny. Stworzenie bezpiecznej, stabilnej, przewidywalnej i silnej więzi jest zadaniem trudnym i wymagającym, a jednocześnie fundamentalnym dla wspierania rozwoju dziecka.

Dyscypliną/dziedziną/teorią, która zajmuje się badaniem wpływu wyobrażonych i realnych relacji na rozwój człowieka, jest psychoanaliza. Znajduje się ona na pograniczu dwóch pozornie przeciwstawnych sobie obszarów - nauki, bowiem jest specjalistyczną, zweryfikowaną badawczo metodą wspierania wszechstronnego rozwoju człowieka oraz formą sztuki, procesem wysoce twórczym, nieoznaczonym i nieskończonym ${ }^{4}$, którego współorganizatorami i kreatorami są terapeuta i pacjent. Terapia, jako aktywność rozpoczynająca się od relacji, powinna stać się jednym z trzech fundamentów pracy z dziećmi z zaburzeniami ze spektrum autyzmu. Pozostałe dwa fundamenty stanowią: a) bardzo dokładna znajomość przebiegu typowego rozwoju dziecka (psychologia rozwoju człowieka) oraz b) zdolność identyfikowania przejawów przeżywanych przez dziecko trudności, nie zaś właściwością osobowości (psychologia kliniczna i psychopatologia) 5 . Aby dobrze wykorzystać możliwości terapeutyczne wynikające z uwzględnienia wspomnianych dyscyplin, przed rozpoczęciem pracy z dzieckiem bardzo istotne jest dokonanie precyzyjnej i pogłębionej obserwacji. Ta, jeśli poparta specjalistyczną wiedzą, pozwala dokonać wstępnej diagnozy funkcjonowania dziecka w świecie i określić poziom jego psy-

4 Por. A. Kępiński, Poznanie chorego, PWN, Warszawa 2013.

${ }^{5}$ A. Alvarez, op. cit. 
chicznego rozwoju. Bez odpowiedniej znajomości prawidłowości rozwojowych czy psychopatologii bardzo łatwo jest przeoczyć istotne dla procesu terapeutycznego informacje lub - co gorsza błędnie ocenić obserwowane u dziecka reakcje ${ }^{6}$. Wydaje się, że we współczesnej praktyce klinicznej, zorientowanej na identyfikowanie deficytów i oznaczanie obszarów "do naprawy", do takich sytuacji dochodzi często. Rozumienie autyzmu jako procesu, którego zatrzymanie/zahamowanie warunkowane jest utworzeniem z dzieckiem relacji (co jest możliwe wtedy, gdy dorosły widzi dziecko całościowo i traktuje podmiotowo), przeciwdziała tej tendencji i sprzyja humanizowaniu pracy terapeutycznej.

\section{Terapia relacyjna jako połączenie emocji i poznania}

Terapia relacyjna angażuje nie tylko umysł terapeuty, ale i jego serce. $Z$ jednej strony wymaga dużej wnikliwości i uważności, szybkiego przetwarzania informacji oraz elastyczności w działaniu będącym odpowiedzią na zachowanie dziecka. Z drugiej zaś związana jest $z$ emocjonalnym wysiłkiem, bowiem terapeuta obdarza dziecko prawdziwie silnymi uczuciami (sympatia, miłość, troska) i jednocześnie odciąża dziecko z tych, które ono samo przeżywa (lęk, złość, bezradność, poczucie beznadziei, pustka). Z czasem wręcz spotkania terapeuty $\mathrm{z}$ dzieckiem stają się podobne do spotkań dwojga zakochanych, niezwykle wyczulonych na płynące od siebie sygnały. Stają się bardzo podatni na działanie silnych emocji doświadczanych w kontekście dopiero co konstytuującej się relacji. I choć oczekiwania względem obiektu miłości są u zakochanego oraz $\mathrm{u}$ terapeuty całkiem różne, pierwszy pragnie poznać ukochaną i wygrać jej serce, a drugi wchodzi z dzieckiem w bliski kontakt, by móc je wspierać. Obie sytuacje mają wspólny mianownik - jest nim silna intencja zbudowania relacji, emocjonalne zaangażowanie oraz

${ }^{6}$ I reakcje świadczące o postępach i rozwoju zakwalifikować jako patologiczne, czy "trudne". 
otwartość na nowe (i niespodziewane) doświadczenia7. Emocje, które przeżywa i okazuje dziecku terapeuta - sympatia, życzliwość, żywe zainteresowanie, troska i inne - muszą być prawdziwe i głębokie. Nie mogą być wynikiem wyuczenia się określonej techniki czy strategii, nie powinny być traktowane mechanicznie, jako zalecane narzędzie $\mathrm{w}$ terapii. (Takie rozumienie postawy i roli terapeuty wydaje się być wysoce nieetyczne i nieakceptowalne w pracy $\mathrm{z}$ drugim człowiekiem). Terapeuta pracujący z dziećmi z zaburzeniami ze spektrum autyzmu, aby być skuteczny, musi umieć, ale i chcieć "zakochiwać się" w swych małych pacjentach i obdarzać pozytywnymi emocjami. Intensywne, pozytywne emocje pozwalają stopniowo rozpuszczać autystyczny lód i ogrzewać chłodny, bo dotychczas samotny świat, w którym dziecko żyło ${ }^{8}$. Pomagają rozpalać wewnętrzny ogień, ocieplają i koją rozedrganą duszę ${ }^{9}$, wzbudzają pragnienie poznawania otaczającego świata, innych ludzi, ułatwiają wydostawanie się z autyzmu.

\section{Terapia relacyjna krok po kroku}

Kluczowym elementem procesu wspomagania rozwoju starszego dziecka $\mathrm{z}$ autyzmem jest relacja $\mathrm{z}$ terapeutą. Jednak w przypadku młodszych dzieci pierwszą osią oddziaływań bywa zazwyczaj relacja z rodzicem, uznana jako niezbędna dla prawidłowego rozwoju dziecka. Podstawowym zatem zadaniem terapeuty w pracy $\mathrm{z}$ małym dzieckiem staje się nawiązanie dobrego kontaktu $\mathrm{z}$ jego rodzicami. Właściwie już od pierwszego spotkania rodzice zostają przez niego uwrażliwieni na płynące od dziecka subtelne, delikatne, niekiedy prawie niezauważalne sygnały - wszelkie przejawy chęci komunikowania się z otoczeniem. Reakcje te mogą być i są

${ }^{7}$ B. Salomonnson, M. Salomonnson, Dialogues with children and adolescents. A psychoanalytic guide, Routledge, London 2016.

${ }^{8}$ A. Alvarez, op. cit.

${ }_{9}$ S. Spensley, Frances Tustin, Routledge, London 1995. 
zwykle bardzo słabe, znacząco opóźnione lub nieadekwatne do wieku metrykalnego dziecka ${ }^{10}$. Stąd też często, aby mogły one być w ogóle dostrzeżone i odpowiednio zrozumiane, potrzebna jest pomoc trzeciej strony - specjalisty. Odpowiedź na komunikat dziecka, sformułowana przez rodzica (z pomocą terapeuty), działa wzmacniająco i zwrotnie zachęca samego podopiecznego do podejmowania kolejnych prób porozumiewania się ze światem. Dzięki responsywności rodzica dziecko jest do tego zmotywowane, pomimo że komunikacja werbalna może być dla niego bardzo trudnym i wymagającym zadaniem.

Kolejnym priorytetowym zadaniem terapeuty w pracy z dziećmi autystycznymi jest wyciszenie (wyregulowanie, nie ich stłumienie!) silnych emocji i ukojenie samego dziecka oraz jego rodziców ${ }^{11}$. Dziecko z zaburzeniami ze spektrum autyzmu często doświadcza bowiem stanów trudnej do opanowania ekscytacji związanej z przeżywaniem przez nie zarówno pozytywnych, jak i negatywnych doświadczeń, a dokładniej odbiorem bodźców ze świata zewnętrznego. Stany ekscytacji na poziomie biologicznym związane są z niemożnością utrzymania równowagi poziomu pobudzenia organizmu i dużą jego dynamiką/zmiennością w czasie. Zamiast stabilnego poziomu napięcia potrzebnego do życia i działania, a charakterystycznego dla przeciętnego układu nerwowego, u dziecka z autyzmem zaobserwować można stany niezwykle wysokiego pobudzenia12 (wyrażające się aktywnością ruchową, dużą zmiennością, podejmowaniem licznych działań, szybkimi reakcjami itp.) występujące naprzemiennie z okresami wycofania i bierności (dystansowania się, izolowania, odcinania od napływających bodźców, również na poziomie psychologicznym). Te reakcje są spowodowane, jak się wydaje, niewielką zdolnością dziecka do filtrowania wrażeń i odbieraniem wszystkich docierających do niego informacji w ten sam, intensywny sposób. Natłok napływających danych silnie

\footnotetext{
10 A. Alvarez, op. cit.

11 S. Spensley, op. cit.

12 A. Alvarez, op. cit.
} 
pobudza, a następnie przeciąża wrażliwy układ nerwowy oraz powoduje wycofanie się i izolację. Dziecko autystyczne funkcjonuje zero-jedynkowo, przyjmując wszystko, bez różnicowania i wartościowania tego, co do niego dociera, albo też nie przyjmując niczego - zamykając się na wszelkie doświadczenia oferowane przez innych. W jego świecie wewnętrznym panuje chaos lub pustka, a żaden z tych stanów nie sprzyja całościowemu wzrostowi i rozwojowi. Brakuje możliwości wyregulowania ilości i jakości odbieranych bodźców, a następnie ich uporządkowania oraz zbudowania stabilnej i trwałej struktury psychicznej, jaką jest Ja. Taką funkcję wyciszająco-porządkującą - początkowo musi wypełniać więc terapeuta, który staje się dla dziecka zewnętrznym regulatorem i którego działania z czasem zostaną przez dziecko przyjęte i uwewnętrznione. Aby jednak ów proces modelowania i internalizacji mógł dojść do skutku, między dzieckiem a dorosłym zawiązana musi zostać relacja.

Wśród dzieci autystycznych wyróżnić można przynajmniej trzy podgrupy, które różnią się od siebie stosunkiem do otaczającego je świata. Zakwalifikowanie dziecka do jednej z nich jest podstawowym zadaniem terapeuty rozpoczynającego proces diagnostyczno-terapeutyczny. Dzięki temu możliwe staje się oszacowanie, czego dziecko nie może, a czego nie chce się podjąć oraz zaplanowanie takich oddziaływań, które mogłyby na ów stan bierności adekwatnie wpłynąć (działania edukacyjne - gdy dziecko czegoś nie potrafi lub też oddziaływania związane $\mathrm{z}$ wzbudzaniem motywacji wewnętrznej - gdy czegoś nie chce) $)^{13}$. Pierwszą podgrupę z trzech już wspomnianych stanowią dzieci, które nie potrafią opuścić swojego autystycznego azylu - są zagubione i bezradne. Nie znają zewnętrznego świata, nie rozumieją też własnych doświadczeń i przeżyć. Dzieci z tej grupy potrzebują przede wszystkim odpowiednich narzędzi/kompetencji do tego, aby móc otworzyć się na innych oraz dobrze radzić sobie w sytuacjach przebodźcowania/przeciążenia (identyfikować te sytuacje i dbać o własny kom-

\footnotetext{
13 Ibidem.
} 
fort oraz dobrostan). W drugiej z wyróżnionych podgrup znajdują się dzieci, które wiedzą jak i potrafią opuszczać swój autystyczny świat, lecz nie robią tego, bo to, co widzą na zewnątrz, wzbudza ich niepokój. W konfrontacji ze światem zewnętrznym odczuwają lęk, niekiedy przerażenie. Wolą nie dopuszczać do kontaktów z innymi, gdyż tracą wtedy poczucie bezpieczeństwa. Takim dzieciom nie potrzeba strategii, dzięki którym będą mogły otwierać się na zewnętrzny świat. Te udało im się już opanować. Dzieciom tym potrzeba przede wszystkim licznych pozytywnych doświadczeń w kontakcie z innymi ludźmi, które stanowić będą przeciwwagę dla już nabytych lub przewidywanych negatywnych wrażeń. Wielokrotnie przeżywane, powtarzające się radosne chwile spędzane z drugim człowiekiem budują z czasem silne przekonanie o tym, że świat zewnętrzny wcale nie musi być źródłem przykrości czy dyskomfortu, a przynosić może przyjemność i zadowolenie. Dają poczucie akceptacji i zrozumienia oraz bycia we wspólnocie z innymi - grupie, która staje się oparciem w sytuacjach trudnych i bolesnych. Podobnych doświadczeń brakuje dzieciom z trzeciej, ostatniej grupy, które choć potrafią i mogą wyjść ze swego autystycznego świata, to jednak tego zrobić nie chcą - alternatywa wydaje się mało zachęcająca. Takim dzieciom bardzo brakuje wewnętrznej motywacji do kontaktowania się z innymi oraz podejmowania wysiłku budowania relacji. Ze względu na uprzednie liczne mało sycące doświadczenia społeczne, dzieci z trzeciej grupy nie dostrzegają sensu podejmowania kolejnych prób współbycia z innymi. Zwykle czują się przez ludzi nierozumiane, niedoceniane, niekiedy w ogóle niezauważane. Jednocześnie nie dążą do kontaktu z innymi, bowiem same nie wartościują pozytywnie tego, co mogłyby od kogoś dostać. Trzy opisane podgrupy różnią się przede wszystkim kolorytem dominujących emocji przeżywanych przez należące do nich dzieci. Różnią się również pod względem zapotrzebowania na interwencje, jakie powinien lub mógłby podjąć najpierw terapeuta chcący wspierać ich rozwój. Tym istotniejsze staje się więc określenie, do której grupy należy dziecko, by efektywnie z nim współpracować. 


\section{Strategie terapeutyczne}

Pierwszą strategią, która pozwala terapeucie zbudować z dzieckiem wystarczająco dobrą i bezpieczną relację, jest obserwacja. To akt wymagający skupienia, spostrzegawczości, szybkiego przetwarzania napływających informacji, a także zdolności do receptywności i nastawienia na swobodny, nieukierunkowany odbiór informacji napływających od dziecka. Idealnie jest, jeśli udaje się obserwować dziecko, utrzymując wolny od uprzedzeń i etykiet, czysty, niczym niezakłócony umysł. Proces ten przypomina nieco malowanie obrazu na niezapełnionej wcześniej karcie i bez uprzedniego pomysłu, jaki on będzie. Taki stan gotowości na przyjęcie dziecka, jakim ono jest, wymaga stworzenia mu odpowiedniej przestrzeni - miejsca, które może zająć w umyśle terapeuty. Aby było to możliwe, przynajmniej na czas spotkania z dzieckiem, terapeuta powinien odłożyć na bok, zawiesić angażujące go poznawczo i emocjonalnie prywatne sprawy. Jednocześnie, jeśli wdzierają się i pojawiają zamiast myśli o dziecku, powinien także umieć korzystać z nich jako dodatkowych informacji dotyczących jakości z nim relacji. Kontakt $\mathrm{z}$ dziećmi autystycznymi często powoduje bowiem wzbudzenie wielu intensywnych uczuć: pustki, nudy, poczucia braku, stanu zmrożenia, sparaliżowania, zniechęcenia, konieczności zajęcia się własnymi sprawami ${ }^{14}$, znalezienia czegoś, czego można się „złapać" i o czym myśleć, aby uwolnić od poczucia skrępowania i sztywności, którymi „,zaraża” się dziecko. W takiej sytuacji nieodpartej chęci ucieczki lub działania, obserwacja, czyli przyjęcie i utrzymanie postawy receptywnej, pozwala uniknąć przedwczesnych, podszytych lękiem i niepewnością decyzji i interwencji terapeutycznych. Daje możliwość uszanowania charakterystycznego, indywidualnego tempa rozbudzającego się w dziecku pragnienia rozwoju. Rozwój bowiem nie może być nienaturalnie przyspieszany i nie stanie się nigdy wynikiem jakiejkolwiek presji wywieranej

${ }^{14}$ M. Zalewska, Dziecko a autoportrecie z zamalowana twarza, Wydawnictwo Czarna Owca, Warszawa 1998. 
przez otoczenie ${ }^{15}$. Warunkiem rozwoju jest wolność osobowa jednostki, do podejmowania decyzji i brania odpowiedzialności za konsekwencje, jakie za sobą niosą oraz ponadosobowa, związana z wolnym od przemocy środowiskiem, w jakim żyje.

Pospieszany czy ponaglany nie może być również proces wzajemnego dopasowywania się dziecka i terapeuty. Poznawanie się, oswajanie ze sobą, przyzwyczajanie do własnego towarzystwa, reakcji i preferencji wymaga czasu i chęci z obu stron. Tempo pracy musi więc zostać dostosowane do potrzeb obojga, bowiem relacja, aby była lecząca, musi być źródłem przyjemności i satysfakcji zarówno dla dorosłego, jak i dla dziecka. Jednakże w takiej relacji to zawsze dorosły/terapeuta jako dojrzalszy i bardziej doświadczony stara się wprowadzać takie interwencje, które mogą być przez dziecko przyjęte i uwewnętrznione ${ }^{16}$. Jego zadaniem jest bycie w relacji, a jednocześnie ponad nią, czyli nieustanne obserwowanie tego, co dzieje się między nim a dzieckiem, aby możliwe było monitorowanie dobrostanu i postępów dziecka, a także identyfikowanie pojawiających się $\mathrm{w}$ danym momencie potrzeb $\mathrm{i}$ adekwatne na nie reagowanie.

Drugą ze strategii terapeutycznych służących nawiązaniu kontaktu z dzieckiem autystycznym jest odzwierciedlanie, czyli zjawisko zachodzące naturalnie w każdej wystarczająco dobrej relacji między rodzicem a niemowlęciem, wspierające rozwój dziecięcego umysłu. Technika ta polega na specyficznym włączeniu się w aktywność dziecka w taki sposób, który przykuje jego uwagę, a jednocześnie który nie będzie dla niego ani zbyt natarczywy, ani intruzywny, czyli odbierany jako akt przemocy (wdarcia się na "teren” dziecka, którego ono bardzo broni). To ważne, ponieważ w wymianie tej nie chodzi jedynie o proste naśladowanie czynności realizowanych przez jednego z uczestników interakcji, ale o poczucie zgodności, spójności, wspólnoty i podobieństwa, które zbliżają do

${ }^{15}$ M. Harris, E. Bick, The Tavistock Model: Papers on child development and psychoanalytic training, Karnac, London 2011.

16 A. Alvarez, op. cit. 
siebie dwie początkowo obce sobie osoby. Pojęcie odzwierciedlania (ang. mirroring) nie bez powodu kojarzy się z odbiciem lustrzanym, bowiem na najbardziej podstawowym poziomie (behawioralnym), odzwierciedlanie przejawia się w podjęciu tej samej aktywności, którą inicjuje dziecko (dziecko rysuje - terapeuta rysuje, dziecko skacze - terapeuta skacze, dziecko śpiewa - terapeuta śpiewa). Takie zachowanie terapeuty jest najłatwiejsze dla dziecka do zaobserwowania, więc najskuteczniejsze na samym początku procesu diagnostyczno-terapeutycznego i/lub w pracy z dziećmi z poważnymi trudnościami. Wydaje się, że dużą rolę $\mathrm{w}$ procesie tym odgrywają neurony lustrzane, dzięki aktywności których dziecko jest w stanie zauważyć naśladujące go osoby. Odzwierciedlanie może jednak zachodzić również na wyższych, mniej konkretnych, a bardziej symbolicznych poziomach złożoności. Zamiast prostego naśladowania zachowań dziecka, terapeuta odwołujący się do wyższego poziomu odzwierciedlania może $w$ reakcji na działanie dziecka odpowiedzieć gestem, mimiką lub wykorzystując wyrazy dźwiękonaśladowcze (dziecko skacze - terapeuta mówi „hop!”, dziecko jedzie autkiem - terapeuta szybko macha ręką i mówi „ziuuum”). Tym samym odchodzi od konkretności - tożsamej reakcji na zachowanie dziecka, a wprowadza reakcję nieco inną, bardziej skomplikowaną i wymagającą od dziecka wysiłku w odnalezieniu analogii do tego, co ono samo robi. Na kolejnym, trzecim poziomie terapeuta odzwierciedlający dziecko może już nie tylko nie robić tego samego co dziecko, nie tylko nie odpowiadać gestem czy mimiką, ale nazwać prostymi słowami to, co dziecko robi (dziecko skacze - terapeuta mówi „skaczesz”, dziecko pije - terapeuta mówi „pijesz”). Ten poziom jest już znacznym odwołaniem się do symbolicznego myślenia, bowiem na zachowanie dziecka dorosły reaguje słowem - pojęciem, swoistą etykietą uchwytującą symbolicznie to, co dziecko robi. Autystyczne dzieci, ze względu na konkretny charakter ich myślenia, często początkowo nie zauważają powiązania między realnym zachowaniem a symbolicznym słowem. Do osiągnięcia tego poziomu dąży się zatem w terapii, zaczynając od etapów niższych, łatwiejszych. Jeszcze bardziej wysublimowany 
i symboliczny jest poziom kolejny, czwarty, gdy terapeuta oprócz prostych słów opisu rzeczywistości zewnętrznej wprowadza terminy opisujące świat wewnętrzny dziecka, tj. stany mentalne, takie jak emocje, myśli, pragnienia, intencje, przekonania i temu podobne. Wydaje się, że najłatwiej i najszybciej trafiające do dziecka są te pojęcia, które odnoszą się do jego intencji, tzn. „chcenia” i stąd też od nich warto zaczynać pracę na tym poziomie odzwierciedlania (dziecko sięga po kubek i wodę - terapeuta mówi „chciałeś się napić"). Poziom czwarty jest już bardzo złożony i symboliczny. Wymaga od dziecka dużej spostrzegawczości i zdolności do łączenia ze sobą różnych faktów (nie mówiąc o zdobytej na wcześniejszych etapach zdolności do koncentrowania uwagi na tym, co mówi druga osoba, z którą dziecko jest w relacji). Taka interwencja ze strony terapeuty pomaga podopiecznemu jednak rozpoznawać pojawiające się w jego doświadczeniach stany i stopniowo porządkować wewnętrzny chaos. Poziom ten w pełni odnosi się do tego, co przeżywa samo dziecko, a jego celem jest wspomóc je w lepszym rozumieniu samego siebie. Na ostatnim poziomie odzwierciedlania terapeuta wykorzystuje wcześniej podejmowane strategie, szczególną uwagę zwracając na zachowania (rzeczywistość zewnętrzna) i stany mentalne (rzeczywistość wewnętrzna) podopiecznego, lecz jednocześnie odnosząc je do swojej osoby, czyli tego, co dzieje się w jego i dziecka relacji. Odwołanie się do niej, np. rozumienie włączania i wyłączania światła przez dziecko na początku sesji jako wyraz witania się z terapeutą po dłuższej przerwie, jest ukoronowaniem pierwszej fazy terapii związanej z budowaniem trwałej i stabilnej więzi między dzieckiem a terapeutą. Wprowadzanie takich interwencji wymaga zdecydowanie czasu i dużych zasobów po stronie autystycznego dziecka. Bardzo trudnym i obciążającym byłoby wdrażanie ich już na samym początku terapii lub w stosunku do dziecka z poważnymi trudnościami rozwojowymi17. Mogą być one wtedy nie tylko nieskuteczne, bo niezrozumiałe dla dziecka, ale mogą wręcz wzbudzać lęk i niepotrzebny niepokój w relacji z tera-

\footnotetext{
17 Ibidem.
} 
peutą. A to, co wydaje się pomagać autystycznemu dziecku najbardziej, to zapewnianie relacyjnego bezpieczeństwa, zrozumienia i doświadczenia przyjemności w kontakcie.

\section{Podsumowanie}

Terapia relacyjna nie jest remedium na wszelkie trudności dziecka $\mathrm{z}$ autyzmem. Nie jest jedyną, polecaną metodą wspierania jego rozwoju. Powinna być jednak ważnym elementem spójnego, całościowego programu edukacyjno-terapeutycznego. Wstępem do podejmowania kolejnych, zorientowanych edukacyjnie działań uczenia się, które zawsze zachodzi w relacji z drugą osobą, będącą dla dziecka nauczycielem. Terapia relacyjna jest sposobem rozumienia potrzeb dziecka z zaburzeniami rozwoju, opartym na trzech solidnych podstawach - wiedzy z zakresu psychoanalizy, psychologii rozwoju człowieka i psychopatologii. Jest wynikiem uważnej analizy normatywnego rozwoju i identyfikowania tych intuicyjnych reakcji opiekuna, które naturalnie wspierają dziecko. Kontakt i relacja powinny być osią wszelkich podejmowanych względem dzieci autystycznych oddziaływań, aby z czasem, dzięki ciepłej, życzliwej, opartej na sympatii i miłości względem drugiego człowieka postawie terapeuty, autystyczny lód tajał ${ }^{18}$.

\section{Bibliografia}

Alvarez A., The thinking heart: three levels of psychoanalytic psychotherapy with disturbed children, Routledge, London 2012.

Harris M., Bick E., The Tavistock Model: Papers on child development and psychoanalytic training, Karnac, London 2011.

Kępiński A., Poznanie chorego, PWN, Warszawa 2013.

18 Ibidem. 
Salomonnson B., Salomonnson M., Dialogues with children and adolescents. A psychoanalytic guide, Routledge, London 2016.

Spensley S., Frances Tustin, Routledge, London 1995.

Zalewska M., Dziecko a autoportrecie z zamalowana twarza, Wydawnictwo Czarna Owca, Warszawa 1998. 